\title{
Bepaling van mannekragaanwending en opleidingsbehoeftes t.o.v. narkosetoediening in die Oranje-Vrystaat
}

\author{
E.H. de Wet* \\ Departement Fisiologie, Universiteit van die Oranje-Vrystaat, Bloemfontein 9300 \\ B.J.S. Diedericks en J.M. Hugo \\ Departement Anestesiologie, Universiteit van die Oranje-Vrystaat, Bloemfontein 9300 \\ J.I. de Wet \\ Departement Biostatistiek, Universiteit van die Oranje-Vrystaat, Bloemfontein 9300
}

In Suid-Afrika word narkose deur 'n wye spektrum van mediese praktisyns toegedien - persone wat verskil in kwalifikasies, opleiding en ondervinding. Tog bestaan daar geen behoorlike statistiek oor mannekragaanwending en opleidingsbehoeftes t.o.v. narkosetoediening nie. ${ }^{1}$

In 'n onlangse studie uitgevoer in die O.V.S. is gevind dat $45,6 \%$ van mediese dokters werksaam in die O.V.S. tussen 30 en 39 jaar oud is en dat $87,5 \%$ hiervan mans is. Van hierdie dokters werk $69,1 \%$ buite die akademiese gebied van Bloemfontein. Jaarliks word ongeveer $\mathbf{4 2 0 0 0}$ narkoses buite die akademiese gebied en 38000 narkoses binne die akademiese gebied van Bloemfontein toegedien. Slegs 5,6\% van medici werksaam in die O.V.S. het spesialisnarkotiseurkwalifikasies, terwyl $66,6 \%$ van die dokters 'n Baccalaureusgraad in Geneeskunde het. Daarvan is $8,1 \%$ geïnteresseerd om M. Med. (Anes) en/of GFN (SA) te behaal, terwyl $76 \%$ nie in verdere kwalifikasies belangstel nie.

Statisties is daar 'n sterk verband tussen opleiding en ondervinding $\left(\mathrm{p}_{h} 0,01\right)$, soos blyk daaruit dat die meerderheid van dokters meer as slegs internskap as opleiding het en reeds langer as 6 maande ondervinding van narkosetoediening het. Versoeke is vanaf perifere hospitale ontvang in verband met 'n rondreisende spesialisnarkotiseur-lektor wat perifere hospitale vir 'n tydperk kan besoek. Dit sal meebring dat hierdie persoon kennis en inligting na buite kan uitdra, sodat persone nie nodig het om vir sodanige tydperk in 'n akademiese hospitaal onder toesig te werk nie.

$51 \%$ van die mediese dokters is ontevrede met hul voorgraadse opleiding in narkose. Die grootste rede hiervoor is as "te min prakties" aangegee. Hoewel $81,5 \%$ tans tevrede is met hulle werksomstandighede, is daar 'n duidelike afname in werksbevrediging met toenemende ouderdom.

Uit hierdie studie blyk dit dat dit die jonger dokter is wat narkose gee en werksbevrediging daaruit put. $\mathrm{Hy}$ werk meestal onder nie-akademiese omstandighede met minimale akademiese kwalifikasies. Tog sien hy die behoefte vir verbreding van sy kennis in en wil dit graag so maklik moontlik bekom. Hy is bereid om opknappingskursusse by te woon, maar moet tyd laat om met ander vakgebiede tred te hou.
Met die koms van rekenaartegnologie het narkose 'n hoogsgespesialiseerde vakgebied geword wat hoë "basiese" vereistes stel. Dit is 'n vakgebied met van die hoogste morbiditeit vir sowel die geneesheer as die pasiënt. Praktiese vaardigheid dra egter baie by tot 'n laer morbiditeit en groter werksbevrediging daarom waarskynlik die groot behoefte aan praktiese opleiding, voorgraads asook nadat MB. ChB. behaal is. Wetgewing in verband met minimumvereistes van opleiding en ondervinding moet dalk hersien en gewysig word.

In Suid-Afrika speel dienslewering deur medici 'n baie belangrike rol - nie net in die privaat praktyk nie, maar ook in 'n gesalarieerde beroep. Dit bly egter die plig van akademici om navorsingsinligting in en van die buiteland te bekom en om self nuwe begrippe na te vors en te bestudeer. Hierdie inligting moet dan oorgedra word sodat ons ons doel - dat 'n medikus ' $n$ veilige narkose in sy omstandighede kan gee - kan bereik. Dit is daarom gepas dat 'n rondreisende spesialisnarkotiseur-lektor nie-akademiese gebiede sal besoek ten einde produktiwiteit en kwaliteit van narkose op die platteland te bevorder en om 'n metode te vind om praktiese opleiding te verbeter.

Opsommend kan dan gesê word dat hierdie studie bewys het dat die meeste medici in die O.V.S. onder nie-akademiese omstandighede werk waar dan ook die meeste narkosegevalle hanteer word. Die behoefte aan praktiese opleiding is veel groter as die behoefte om 'n nagraadse narkosekwalifikasie te behaal. 'n Rondreisende spesialisnarkotiseur-lektor verbonde aan 'n nabygeleë akademiese instansie mag produktiwiteit en kwaliteit van narkose in die platteland bevorder.

Kort nadat hierdie studie voltooi is, het een van die outeurs (J.M.H.) alle plattelandse hospitale in die O.V.S. besoek. Die doel was om narkosetoerusting te inspekteer, behoeftes vir vernuwing te identifiseer en om geneeshere te ontmoet. Geneeshere is oor nuwe narkosetoerusting en verbetering van veiligheidsmaatreëls tydens narkose ingelig. Hierdie besoeke het vrugbaar verloop en bevindinge van die studie is deur persoonlike kontak bevestig. So is ook die nodigheid vir opvolgwerk duidelik besef.

VERWYSINGS

1. Rocke, D.A. (1986): Anaesthetic manpower and training, $S$. Afr. Med. J., 69, 159. 